Part I

Negotiating tradition 

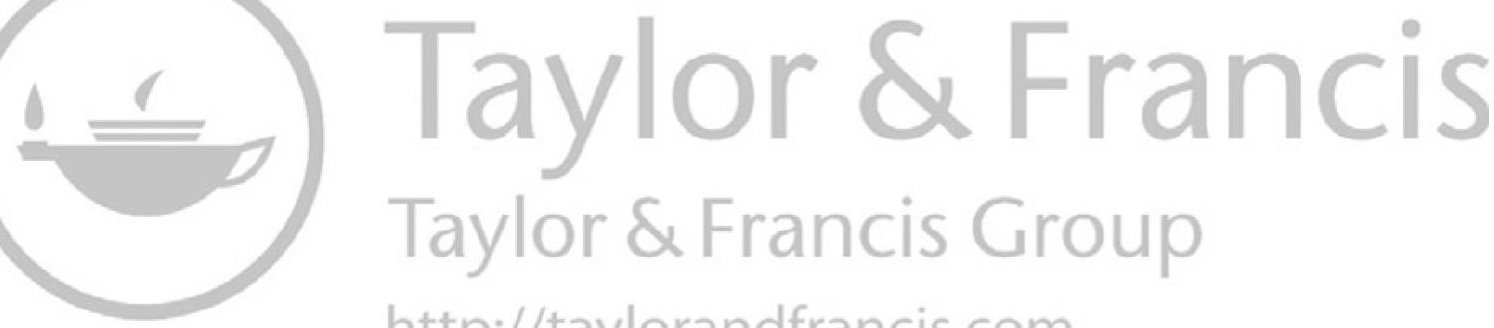

http://taylorandfrancis.com 


\title{
2 Gender and Orthodox theology
}

\section{Vistas and vantage points}

\author{
Brian A. Butcher
}

A provocative recent issue of the journal The Wheel: A Journal of Orthodox Christian Thought assembled a spectrum of Orthodox thinkers to reflect on the theme of "being human," including such subthemes as "embodiment and anthropology" and "sex, marriage and theosis." The publication aimed to draw attention to how Orthodoxy is or should be engaging with the controversies of our day regarding gender-a term often serving metonymically to connote other debates, whether of a psychological, philosophical, or indeed theological order. Brandon Gallaher neatly articulates the dilemma faced by Orthodoxy on this front as it seeks to eschew traditionalism while preserving tradition-a distinction rendered by Jaroslav Pelikan $(1986,65)$ as that between the "dead faith of the living" on the one hand and on the other, the "living faith of the dead":

To be blunt: should we pay attention to the natural law reasoning of the fathers if we ignore their outdated cosmologies? When it comes to the tradition, we all pick and choose. We must pick and choose with tradition! But the question is: what are the appropriate bounds of that theological picking and choosing? What does and does not constitute a normative standard in the tradition? What are the bounds of the perpetual reinvention of tradition?

(Gallaher 2018, 62)

Gallaher's expansive questions are perhaps best addressed with an analogy drawn from hiking, inasmuch as the scholar who would explore the landscape of gender within Orthodox Christianity faces logistical challenges well known to those embarking on a trek. To wit: one has to stand somewhere in order to see the lay of the land, and yet the place one chooses cannot, for that very reason, be encompassed in the perspective which it affords. Hence the title of this chapter: accessing the thematic vistas relevant to the topic requires conceding the stability and yet relative invisibility of those loci theologici (theological sites) from which the widest views are to be had.

What are these vantage points? Orthodox theology characteristically appeals to Holy Tradition writ large, differentiated according to a number of sources: usually, the Scriptures, the fathers, the Ecumenical Councils and 
their legislative/disciplinary canons; the Liturgy and the Holy Mysteries or sacraments-namely, the "law of belief" (lex credendi) expressed through the received "law of prayer" (lex orandi)—as well as hagiography and iconography (Louth 2013). Modern church teaching is often added to this list, especially when it is articulated by synods of bishops rather than by individual theologians. To canvass these sources for all the material pertinent to gender studies would be a formidable task indeed and well beyond the scope of an overview.

A more expedient approach, therefore, is to propose certain key vistas and in turn, descry how they appear from one or more of the vantage points indicated. This is the method I use here by asking how the following topics, each an aspect of classical theological anthropology in the Orthodox Christian tradition, present themselves to view: humanity as made in the image of God; Christ and the Theotokos as the respective exemplars of paradigmatic male and female humanity; the Trinity as the model for the self-in-relation; and marriage and monastic celibacy as the two blessable states of life.

Surveying these vistas from the height of the loci theologici enumerated above allows me to sketch the contours of an Orthodox "theology of gender," as this has traditionally been envisaged-if not in so many words. To facilitate a critical dialogue between the Orthodox tradition and other academic disciplines-for example, to limn the social imaginary operative in the kind of case studies presented throughout this volume-it seems prudent to reflect upon how Orthodox have historically understood the meaning of gender difference theologically, that is, from within the particularity of their own religious Weltanschauung. ${ }^{1}$

\section{Humanity as made in the image of God}

A good place to begin is by considering how Eastern Christians have understood the nature of things "in the beginning": the Biblical book of Genesis has proven a site of patristic theological reflection par excellence, intensely interested as the fathers were in questions of human origins, identity, and purpose. Running throughout such reflection is a focus on humanity being created imago Dei (in the image of God) as per Genesis 1:26, with several of the fathers distinguishing between the divine image objectively present in all human beings and the divine likeness we are called, by and through grace, to acquire. Important here is that human nature is regarded as a psychosomatic whole: both body and soul are constitutive elements, and salvation must hence include both. Nonna Verna Harrison $(2013,122)$ summarizes the key features of patristic thinking on the imago Dei:

[A]ll humans are endowed with the capacities for love and spiritual perception, for virtues, good works and contemplation. (...) Together with the freedom to choose how they are utilized, they are the means 
through which the human person can pursue and fulfill his or her vocation precisely as human. They are thus the most important facets of human identity. They enable us, in synergy with divine grace, to live as active, loving members of Christ's Body and of his Kingdom, both in this life and in the life to come.

Now the God in whose image we are made is, in the Orthodox understanding, Trinitarian: our ability to relate to others, therefore, is also an essential aspect of the imago Dei. As Harrison $(2013,123)$ continues:

[Such] capacities (...) are definitive features of our existence as hypostases [i.e., as persons]. They delineate our being in the image of the Holy Trinity. They enable us to fulfill our ultimate vocation of sharing the love of the three divine persons with them and with all other human and angelic persons.

Human potential notwithstanding, our actual resemblance to God has been obscured because of the Fall: so-called ancestral sin haunts human experience and is expressed most poignantly in what Heidegger much later aptly termed our "being-toward-death" (Wheeler 2011). In the Eastern Christian understanding, it is this very awareness of our mortality which impels us to $\sin -a$ view grounded in the peculiar reading of Romans 5:12 to be found in the Greek patristic tradition. ${ }^{2}$ Our original capacity for knowing and loving God has been impeded by sin, a "missing the mark" (hamartia) reflected particularly in the vice of pride. As a result, we now possess what St. Maximus the Confessor calls a "gnomic will": one subject to incertitude and deliberation and thus tending to vacillate with respect to the acknowledgment and performance of the good (Meyendorff 1983, 143).

Axial to the theological anthropology outlined above is the premise that human nature is common to both men and women (Hopko 1993, 150). As both are made in the image of God, both suffer the consequences of the Fall. Some Orthodox theologians have therefore taken the force of the creation narrative to be that gender and sexuality are in principle only secondary, albeit necessary, aspects of our humanity. ${ }^{3}$ What is primary is our personhood-a view reiterated in the recreation effected in the Mystery of Baptism by which all alike are born again as little Christs, as it were, through the womb of the church. To be sure, the baptismal liturgy makes almost no distinction with respect to the sex of the candidate: the exact same prayers are sung over both a male and a female baptizand, varying only by referring to the former as the "servant" of God and to the latter as His "handmaid." The theological rationale for this is elucidated in the jubilant processional hymn sung immediately following the rite of Chrismation, adjoined to the baptism proper: "All you who have been baptized into Christ, you have put on Christ. Alleluia!” (Galadza, Roll, and Thompson 2004, 409). 
In principle, baptism thus points to a common Christian vocation which appears to transcend gender difference. As Kenneth Paul Wesche (1993, 227) observes:

All who enter the waters of Holy Baptism put on Christ, the Son of God by nature, and in this putting on of Christ, all men and women receive the grace of His natural Sonship, becoming thereby sons of God by grace. While remaining who and what we are, we move out of ourselves in ecstasis, into the divine Sonship which is beyond gender, enjoying by grace the same intimate communion with the Father which the divine Son enjoys by nature.

And yet even in the course of Christian initiation we encounter a conspicuous marker of gender difference. During the "churching" of a newborn on (or around) the 40th day, a rite which may precede or follow the baptism/ chrismation, the priest carries a baby girl in his arms up to the Royal Doors, whereupon he intones the Nunc dimittis or Song of Simeon (Lk. 2:29-32). For a baby boy, however, the rubrics are otherwise: "The Priest then carries the male infant into the Sanctuary, circling the Holy Altar, and reciting Symeon's prayer" (Contos and Kezios 1995, 18). The import of this still widespread custom is that the baby boy may be taken into the altar as a harbinger of his potential clerical vocation; since Orthodox do not presently ordain women to any order, however, there is ostensibly no reason to do likewise for a baby girl and even reason not to-despite the fact that in the past Orthodox women were indeed ordained to the diaconate in a ritual transpiring at the altar. ${ }^{4}$ Lurking in the background is the further unresolved issue of ritual impurity: a survival into Orthodox Christianity of Jewish and/or pagan views of the allegedly defiling properties of menstruation, which Vassa Larin (2008) has castigated for its theoretical incongruence with the Christian Gospel no less than its debilitating effects upon Orthodox women's spiritual practice.

Nevertheless, an equal-but-different view of male and female is undoubtedly the default setting among Orthodox today. To appreciate why this is the case, we must consider how and why given persons have been held up as paragons of their sex. Who are the heroes and heroines in the Orthodox pantheon, so to speak, and how and why are they so idealized?

\section{Paragons of divin(ized human)ity}

The figures of Christ and the Virgin Mary obviously occupy the central place in Eastern Christian faith and devotion: as Christ is the New Adam, in the understanding of St. Paul expressed in Romans 5:12-19 and 1 Corinthians 15:47, so the Theotokos (Mother of God) has traditionally been seen as the New Eve (Meyendorff 1983, 165). In turn, the two are commonly presented as the exemplars of masculinity and femininity-even as, 
of course, all Christians are called to be like Christ as also imitate the humble declaration of Mary to the Archangel Gabriel at the Annunciation: "Let it be to me according to your word" (Lk. 1:38). ${ }^{5}$ In a Byzantine-rite church, this is illustrated by men traditionally standing on the right side in front of the icon of Christ, always hanging to the right of the Royal Doors, which today mark the entrance to the altar; the women position themselves on the left before the icon of the Theotokos. ${ }^{6}$

Similarly, at the Service of Crowning, it is customary for the bridal couple to have icons of Christ and the Theotokos held up for veneration, on the respective sides corresponding to those of the icon screen, as the husband and wife are led in procession around the tetrapod, a small table located in the nave in front of which the rite has been celebrated. The role played by iconography in the Crowning, as elsewhere in Orthodox religious experience, derives from a theological conviction that the respective heavenly prototypes are not only contemplated in their icons but made present therein.

Importantly, representations of the subjects of icons conventionally represented in such a manner as to highlight their masculinity and femininityfor instance, the maphorion or veil almost always covers the head of a female saint and is emulated in the chapel veil worn by women even today in many Orthodox churches. ${ }^{7}$ One may note that even when an icon does not readily convey the identity of a given saint, the gender is invariably explicit.

The received correlation between Christ and Mary on the one hand, and male and female on the other, receives an intriguing development in the thought of lay theologian Paul Evdokimov, one of the most original and influential Russian Orthodox voices of the twentieth century, whose oeuvre has engendered a substantial secondary literature in its own right. ${ }^{8}$ Peter Phan $(1990,58)$ helpfully summarizes how Evdokimov elaborates analogies on both the Trinitarian and Christological planes. In the former, woman is to the Holy Spirit as man is to Christ; in the latter the equivalencies are the Virgin Mary and St. John the Baptist, who flank the Lord in the classic icon known as the Deisis (Intercession).

As archetypes [these figures] are as it were God's thought and model of the female and the male, their normative, hypostasized truths. And just as the Logos and the Holy Spirit find their unity and source in God the Father, so here too the Virgin Mary and John the Baptist find their unity and integration in Christ, in whom there is neither male nor female (Gal 3:28) but also in whom the woman is not without the man nor the man without the woman (1 Cor. 11:11).

Evdokimov is quintessentially Orthodox in his privileging Trinitarian theology as the context for reflection on the question of gender. Let us look, then, more carefully at the question of how gender figures in the discussion of God qua God. 


\section{The Trinity as model for the (gendered) self-in-relation}

Despite the burgeoning of scholarship on Syriac Christianity in recent decades, it remains an underappreciated fact that, in its early literature, the Third Person of the Trinity was often described in feminine terms, on account of the originally feminine gender of the Syriac (and Hebrew) term for spirit $(r u h a)$. From the fifth century on, however, masculine pronouns come to be used even as the feminine qualities of the Holy Spirit continue to receive emphasis in the Syriac and to some extent the Armenian, liturgical traditions (Ashbrook Harvey 1993). ${ }^{9}$ In this light, Evdokimov can present women as embodying the specific attributes of the Spirit. For him, a proper respect for the diversity of the Trinitarian persons leads to a reverence for the distinctive female vocation as ordered toward being rather than doing: such a vocation expresses a receptivity to God at once emblematic of the royal priesthood to which all the baptized are called and exclusive of the ministerial priesthood, circumscribed as this is by the specifically "masculine" ambit of "penetrating" and (re)claiming the world.

Evdokimov's undeniably essentialist vision-while a cardinal instance, perhaps, of the kind of appeals to fixed and given natures, which according to Kathryn Tanner "help solidify unjust social arrangements and disguise their contingency" (cited in Horan 2014, 97) — continues to intrigue, grounded as it is in a lavishly poetic reading of the second chapter of Genesis and illustrating thereby the enduringly fecund significance of the Creation accounts in Orthodox anthropology. It is worth quoting Evdokimov (1994, 31-2) at length:

Woman has her own mode of being, her own form of existence, the gift of weaving her entire being through her special relationship to God, others, and self. (...) [She] safeguards at the very depth of herself the mystery of her being and of her charisms that St. Paul designates with the symbol of the "veil" (1 Cor. 11). It is this mystery that she must "unveil" and interpret to understand her destiny "nuptially," in close relationship with that of man. The Biblical account (...) is correctly set up as the original archetype of the consubstantiality of complementary principles. The masculine and feminine form the archetypal human monad: Adam-Eve. The Fall breaks up this oneness into a bad masculinity and a bad femininity: couples made of two polarized, objectified, and separate individuals, situated outside each other, placed nonetheless side by side. (...) The nuptial community arises as the prophetic figure of the Kingdom of God: the ultimate unity, the community of the Masculine and the Feminine in their totality in God. ${ }^{10}$

Unsurprisingly, however, such a conclusion has not proven persuasive to all. On the contrary, inasmuch as Christian theology classically begins with the confession of Jesus as Lord-the Word through Whom "was not any thing 
made that was made" (John 1:3) — some have found it quite inadmissible to schematize the relationship of male and female in terms of correlations to the respective divine persons of the Son and Spirit. It is hence contended that the Son subsumes in His own being the entirety of creation, both masculine and feminine properties. He Himself is the consummate Image of the Father: the One Who, to be precise, establishes the proper frame of reference for understanding humanity as created imago Dei. Thus Wesche $(1993,223)$ can insist, following St. Maximus the Confessor (590-662 C.E.):

The Divine Logos is a unity embracing a diversity of principles. Applied to woman this means that even the inner principle of "femaleness" lies in the Logos. And since Jesus is the Divine Logos, then even in his Incarnation as "man," $\mathrm{He}$ is the ontic source of woman. Again, this confirms for us that a true understanding of gender can be acquired only in the context of the doctrine of the Incarnation. To seek an understanding of gender outside the Divine Logos incarnate can yield no ultimately satisfying conclusion.

Yet other voices within modern Orthodoxy have gravitated toward Evdokimov. Thomas Hopko, one of the most influential, similarly bases his reflections on gender in the Trinitarian mystery. Affirming the paradoxical, if not contradictory, notion that God is worshiped "wholly without gender," despite being invoked under the name of "Father," Hopko (1993, 146-147) explains:

Christians are enabled to relate to God as Father because they share in the relationship which God's Son has with God in the Holy Spirit. This does not mean that God is to be conceived or imagined as "male." God is Father to his Son in the Spirit in a divine manner which absolutely excludes gender and sexuality, as it excludes everything which belongs to created nature. In Christ, God becomes Father to men and women by the grace of the Holy Spirit in this same divine manner. According to Orthodox doctrine, Christians do not call God "Father" because they project onto God the characteristics of human fatherhood. Just the contrary. Human fatherhood, which includes being masculine in gender, reflects in a human form, within human conditions, that which God is in a uniquely divine manner.

The import of Hopko's somewhat ambivalent claim is that although sexuality as such is excluded from consideration of the divine nature, gender yet pertains to it. In fact, the Scriptures, and in their wake the Byzantine liturgical tradition, very rarely directly invoke God by means of feminine nouns or pronouns, and the use of apophatic ("negative") terminology radically qualifies the ubiquitous masculine terms. ${ }^{11}$ Nonetheless, the author's admission that human fatherhood reflects divine paternity begs the ensuing 


\section{Brian A. Butcher}

question as to where a companion reference point for motherhood is to be found. The answer is in the determinate character of divine revelation whose system of analogies is mutually dependent: information from Scripture forms a set governed by an intrinsic and irreducible logic:

[Scripture's] gender-related names, images, and symbols are so essential to the Biblical story and the church's faith, together with the liturgical worship and mystical life which they engender, that the story and the faith would not be what they are without them. (...) To change or replace its names and imagery is to change and replace its reality into something totally different from what it is.

$(\text { Hopko 1993, 149) })^{12}$

Now, according to Hopko, this revelatory network exposes a homology between the Holy Spirit, the Theotokos, the church, and Divine Wisdomand, in turn, women generally. The Holy Spirit as the Giver of Life is intimately associated with Mary in the moment of the Incarnation and overshadows in an kindred manner the Church Herself, who "in her sacramental being [is] the foretaste of the cosmos transformed by Christ into the Kingdom of God which is the heavenly Jerusalem, the 'bride of the lamb' who 'is our mother' (Gal 4:26, Rev 21:9)" (Hopko 1993, 154). Even though in the Byzantine tradition it was predominantly Christ who was seen as the personification of Divine Wisdom-a fact illustrated in the dedication of the Cathedral of Hagia Sophia in Constantinople, for which Christmas, the birth in time of the Logos, was chosen as the patronal feast-in the second millennium the title has come instead to denote the Mother of God. Ultimately, this conflation of categories invited the twentieth-century development of Sophiology in the work of Vladimir Solov'ev and then Sergii Bulgakov. $^{13}$

In sum, one notices several distinctive premises. First, there are particularly feminine aspects to the divine character. Second, these are expressed most conspicuously in the person and operations of the Holy Spirit, especially in relation to the genesis of the church, the birth and maturation of believers in and through the Holy Mysteries, and the nuptial consummation of God's love for the world that lies at the heart of Orthodox eschatology. Third, the typologies of masculine and feminine that emerge in and through the church's received practices, that is, her (!) tradition, are an index not only to the mores of marriage itself, but more generally to the peculiar charisms of men and women. Thus, Hopko (1993, 169-170) can conclude:

In the most basic sense man in relation to woman is made to be a giver. Giving is not simply man's function or role in regard to woman; it is the heart of his being as imaging God the Father and Son. (...) She inspires, empowers, and nurtures man to be man in a manner analogous 
to the Holy Spirit's inspiring, empowering, and nurturing Jesus to be the Christ, the church to be his body and bride, and Christians to be God the Father's children.

Such a categorical sense of the givenness of tradition and of its coincidence with nature is arguably an abiding characteristic of Orthodox theology. ${ }^{14}$ Rather than asking whether the difference between male and female is principally ontological or functional, Hopko proposes that the Orthodox tradition intuits an irreducible both/and.

\section{Marriage and monasticism: the two blessable states}

It is commonplace that in the Orthodox Church, as in both the wider Eastern heritage and the Latin West, marriage and monasticism have historically been seen as the principal, if not exclusive, states of life which may receive the blessing of the church. The former expresses gender as complementarity and the latter as sublimated into the "angelic life." Undoubtedly, the theological literature has favored the vocation to celibacy in spite of, or perhaps because of, marriage remaining far more common. John $\mathrm{McGu}$ ckin $(2017,35)$ thus laments:

Orthodox theologians in times past have rarely been able to move their imagination away from marital union considered as an ascetical "lapse": a lesser state of seriousness than single celibacy. The ascetical dimension has so overshadowed thinking on marriage that a deeply scriptural resonance has stood in danger of being lost.

Others, such as Harrison (2013), see recent theology as having overcompensated for the historical privileging of monastic life, with the result that precisely monasticism, and by implication celibacy, is in need of the more robust defense today.

Let us return here to Evdokimov, who $(1985,65-84)$ seeks to square the circle by stating that marital and monastic spirituality are reciprocally connected, rooted in an awareness of the ontological equality and eschatological orientation of both vocations. These two different modes of Christian witness should cross-pollinate and exist in symbiosis, since both marital chastity and monastic celibacy function on the same level of ascesis of the absolute, albeit in distinct modalities. Monks and spouses alike are called to a kind of renunciation that Evdokimov argues is directed toward positively embracing another in love following the verdict of Genesis 2:18: "it is not good for man to be alone." Chastity (sophrosynê) in this connection is taken to be tantamount to "integrity" and "integration" rather than continence. For spouses, it signifies that faithful praxis of nuptial love, which can protect them from the flux of the passions and serve as a kind of propaedeutic or preparatory study for the life of eternity. Indeed, their summons to a 


\section{Brian A. Butcher}

kind of communion renders them in principle a "nuptial icon" of the Trinity, the love of whom is mediated through love of another-even as within the Trinity there is the dynamic mutual exchange of love between the divine persons classically termed perichoresis (rotation or circumincession).

Importantly, Evdokimov's rhapsodic vision of the complete humanity expressed by the man and woman united in marriage evokes what some Greek Fathers have taken to be the prelapsarian androgynous being God created in the first instance prior to its separation into the two sexes. ${ }^{15}$ The corollary of this is that for St. Gregory of Nyssa (335-394 C.E.), inter alia, the life of the future Kingdom recapitulates that of the original creation: it will be one without gender difference (Harrison 2013, 123). And yet the settled conviction of Orthodox theology would appear rather to hold that marriage, and thus the distinction between male and female, has a permanent significance in the divine economy. As Hilarion Alfeyev (2011, 152) explains:

In the Christian East, the words of Christ that the people in the age to come "neither marry nor are given in marriage" but "are equal to the angels" (Luke 20:35-36) have not been taken to mean that marriage comes to an end after death. They show that people's mode of existence in the future will differ from that of this transient world. What constitutes the precise nature of this difference remains a mystery. (...) the mystery of marriage will reveal itself even more fully in the future life, in spite of the fact that sexual intercourse will no longer be possible and our entire bodily condition will change.

Echoing Evdokimov, Alfeyev continues that monasticism is best appreciated as itself a kind of marriage. Far from constituting the opposite of the Mystery of Crowning, it is analogous to it: "[m]onastics are espoused to God Himself" (Alfeyev 2011, 160). As we will see momentarily, such a vision of the monastic vocation is admittedly salient in the church's hymnography. We would be remiss, however, to proceed further without mentioning the significance of married priests, ubiquitous in the Christian East, and especially the role played by the wife of the presbyter-a figure enjoying particular distinction within Orthodox cultures. Her identity and role have increasingly become the object of sustained theological attention, in tandem with a vigorous discussion in Orthodox quarters regarding the revival of the currently all but defunct office of deaconess or woman deacon.

Indeed, the former has been seen as carrying forward the symbolism traditionally associated with the latter. For example, the third-century Didascalia apostolorum famously correlates the roles of the deaconess and the Holy Spirit. It has been suggested that by a kind of transferral the priest's wife has over time acquired a similarly iconic significance, if unofficially so:

[J]ust as the Holy Spirit-who is certainly indispensable in divine economy-is nonetheless thoroughly kenotic in Her vitality to the 
point that even graphic imagery for the Holy Spirit is virtually absent (save the Dove and one or two symbolic images), so also the presvitera's energeiae, as it were, have frequently been powerfully experienced, yet without the kind of articulation typical, on the other hand, for Christ, the incarnate Word.

(Galadza 2015, 45-46)

The titles for the priest's wife further corroborate this view, in the implicit or explicit homologies Eastern Christian sources draw between the Holy Spirit, Mary, and the church (as well as Divine Wisdom). Thus the presvitera is known in Russian and Ukrainian, respectively, as matushka (little mother) and pani matka (lady mother): "Following the example of Mary, the presbytera, fulfilling her role as Icon of the Theotokos, can be that maternal presence in her community, complementing the paternal and apostolic ministry of her husband." 16 The Orthodox tradition has even felt able to speak of a kind of concomitance shared by her and her husband, deeming that her being united "in one flesh" with him effects an implicit ordination. Galadza $(2015,49)$ thus draws attention to the opinion of the revered twelfth-century canonist Theodore Balsamon that "the wives of priests, who are reckoned one body and one priestly flesh through union with priests, who consequently are ordained, so to speak, should not be profaned by second marriage".

Yet Orthodox hagiography includes very few examples of married saints, despite the value elsewhere ascribed to marriage as a sacrament and its acknowledged connection to the Mystery of Priesthood. ${ }^{17}$ Indeed, the overwhelming majority of canonized saints have been monastics, although these expressions of sanctity are at times rather unpredictable and even surprisingly germane to contemporary concerns. Exemplars of what we might call sanctified gender bending are numerous, particularly female saints who pretended to be male in order to join a men's monastery; these are honored for a deception carried out in the pursuit of a more "manly" form of asceticism. ${ }^{18}$ But for the most part, nuns are praised as "brides of Christ" who long to enter into His "heavenly bridal chamber." Notably, male monastics are occasionally described in similar terms. ${ }^{19}$

If nuns serve as the principal icons of the feminine persona of the church, awaiting the consummation of the wedding feast of the Lamb, martyred women are also seen to share in this vocation. Hence the generic troparion for a female martyr can exult: "Your lamb, [name], O Jesus, cries in a loud voice: 'You, O my Bridegroom, I love; and seeking You, I undergo martyrdom," while that for several venerable women (nuns) commemorated together proclaims: "Being espoused to your Bridegroom, $\mathrm{O}$ glorious Christian women, and having renounced union with any temporal suitor (...) you reached the heights of incorruptibility (...)." (Galadza, Roll, and Thompson 2004, 912). Again, for the Forty Holy Women commemorated on September 1, the church sings: "You combined the ascetic life with the contest of martyrdom, and now you have been joined without corruption to 
the Bridegroom of souls, and with joyful souls you take your places in the divine bridal chamber" (Lash n.d.).

Of course, the Virgin Mary herself is repeatedly referred to throughout Byzantine hymnography as both the Unwedded Bride of God and the Bridal Chamber of the Heavenly Bridegroom. Thus women monastics and martyrs are also, in a sense, icons of the Theotokos, reiterating in their own lives and deaths her spousal relationship with God as well as the nuptial mystery of the Church Herself:

Come, and contemplating with pure heart and sober spiritual eyes the loveliness of the Church, the King's daughter, which shines brighter than gold, let us magnify her. Rejoice and be glad, bride of the great King, as clearly reflecting the beauty of your Bridegroom, you cry with your people: O Giver of Life, we magnify you. Grant your Church, O Savior, the defence from on high; for she knows no other but you, who laid down your life for her of old, as with recognition she magnifies you.

(Lash n.d. $)^{20}$

Union with God is thus available to men and women alike, although it tends to be described differently in the liturgical poetry for male and female saints. As we have seen, women saints along with the Virgin Mary tend to be presented as "brides of God" (or alternatively, in the case of such saints but not the Virgin, as "brides of Christ"), while male saints are more readily hymned in non-gendered, even inanimate images-shining as "unextinguishable lights of the Mystical Sun," for example, or flourishing "like the Tree in Paradise" (Galadza, Roll, and Thompson 2004, 916, 922). ${ }^{21}$ The latter imagery tends to prevail when the tradition is performing in a systematic key, as it were. Salvation is more typically conceived in terms of theosis (divinization or deification) apart from explicitly nuptial terms: it is first and foremost a matter of humanity assuming, by grace, divinity. As Stephen Thomas $(2011,183)$ observes: "The fathers used theosis to bring out the high condition to which human beings are exalted by grace, even to the sharing of God's life." Set in relation to the idea of humanity created imago Dei, theosis allows for a distinction without separation between the divine gift of the image, "the human potential to be as Christ, the perfect image of God," and the acquisition by the human being cooperating with the Holy Spirit of the likeness, "the actualization of this in the possession of God-like qualities, that is, human perfection."

\section{Essentialism and exclusivism}

In discussing the charged question of admitting women to Holy Orders, Elisabeth Behr-Sigel and Kallistos Ware $(2000,77)$ reiterate the notion of complementarity between the sexes that is more than skin deep, which 
I have shown to be characteristic of Orthodox theology. They approvingly quote the work of Kyriaki Kardoyanes FitzGerald:

I believe most strongly that maleness and femaleness, as gifts from God, have dimensions that are not only biological but spiritual. I agree (...) that the difference between men and women is "a difference of being which is rooted in the very essence of creation and manifested in the particular expression of personhood." 22

Similarly, in a recent book examining the work of C.S. Lewis from an Orthodox perspective, Edith Humphrey seeks to demonstrate that Lewis sought to express, especially through his fantasy literature, a view of gender and sexuality entirely consonant with Eastern Christian tradition. Male and female are for Lewis but finite and limited expressions of essentially spiritual categories of masculine and feminine whose full import necessarily eludes the compass of human reason and experience alike. As Humphrey (2017, 254) writes:

[Lewis] argues against the idea that the principles of masculinity and femininity are simply a projection of our physically gendered state. It is the opposite. Beyond the human gendered condition, there is something even more solid to which our sexual natures point, and in which we participate-realities of which we can hardly conceived. In this unseen relation of Masculine and Feminine, there is One who is dominant, the Other reflexive and responsive; yet there is also a matching, or a mutuality.

Drawing upon Evdokimov, Humphrey $(2017,258)$ rehearses the analogy between the equality in difference of the Trinitarian persons and that obtaining on a human level. In both God and humanity, there is a "mysterious tension of hierarchy-with-mutuality." Hierarchy as such does not imply inferiority, although it does require subordination or rather deference: "There is an asymmetry in the relationship (the Father is not the Son, Woman is not the Man) even while each is of equal dignity."

As Humphrey well realizes, the key issue is the extent to which we may claim the visible world and its reiteration in language, as an index to the divine-and consequently see revelation as confirming the natural order perceivable to the senses. Metaphor is the fulcrum on which the matter balances:

Is metaphor window dressing for an ineffable concept? Or are some metaphors real, living things that partake of the reality? The one who has a sacramental view of the universe would say, yes, they do. Not all metaphors are mere fancy. 
In other words, the recourse of scriptural language to uniquely masculine titles when invoking God-or, indeed, its casting of the church in feminine terms as the Bride of Christ, the union with whom constitutes the true significance of Christian marriage (Eph. 5:32) -is not reducible to the mores of ancient Israel or the late antique Greco-Roman world in which the texts of the New Testament emerged. Rather, such language has an abiding value as the vehicle of divine revelation, evincing an intentional choice on the part of the God to bespeak (a gendered vision of) Himself to His world. ${ }^{23}$

Increasingly, and perhaps in non-Orthodox contexts especially, such a claim would appear to read as naïve, not to say ridiculous. And there are undoubtedly also Orthodox troubled by the gender binary of received Eastern Christian tradition. Inspired by works such as John Boswell's (1995) (in)famous revisionist history of same-sex unions in the Byzantine world-notwithstanding the recent, ostensibly definitive, refutation of its core thesis by one of the foremost scholars in the field (Rapp 2016) - there is a vocal, if not yet numerically significant, contingent challenging the status quo with respect to the church's nonrecognition of homosexuality. The blogosphere is where the most animated discussions of this topic transpire, for instance, in the eclectic and apparently widely read blog "Orthodoxy in Dialogue." 24 It is also through the internet that tentative movements of solidarity among LGBTQIA+ Orthodox have gained a degree of momentum and diffusion-it being difficult, of course, to ascertain details in this regard with any certainty.

It is not clear that Orthodox Christianity is amenable to transformations that have impacted on other forms of Christianity. That is, Orthodox do not tend to perceive gender as falling within the adiaphora (nonessential) or as a matter on which the church should tolerate a diversity of views and practices. Hopko $(1993,142)$ states categorically:

we speak not about an Orthodox Christian view, but about the Orthodox Christian view. We use the definite article because our faith obliges us to come to complete agreement on this crucial issue which lies at the very heart of our doctrine, worship and witness as human beings and Christian believers.

This tone is only amplified in what is certainly the most authoritative corporate pronouncement on the question, namely the Basis of the Social Concept of the Russian Orthodox Church, issued in the year 2000 by the hierarchy of the largest and most influential of the churches within the Eastern Orthodox communion. Section XII.9 deals with sexuality in an unequivocal manner, likely to shock the reader habituated to the ethos currently prevalent in much of "the West"-an ambiguous designation, as noted below - where "fluidity" of sexual orientation, gender identity, and expression has acquired an ideologically normative status:

Holy Scriptures and the teaching of the Church unequivocally deplore homosexual relations, seeing in them a vicious distortion of the 
God-created human nature. (...) The patristic tradition equally clearly and definitely denounces any manifestation of homosexuality. (...) Addressing those who stained themselves with the sin of sodomy, the St. Maxim the Greek made this appeal: "See at yourselves, damned ones, what a foul pleasure you indulge in! Try to give up as soon as possible this most nasty and stinking pleasure of yours, to hate it and to fulminate eternally those who argue that it is innocent as enemies of the Gospel of Jesus Christ and corrupters of His teaching."

(The Russian Orthodox Church 2000, Section XII.9)

The document denies, then, first that society should recognize nonheterosexual orientations or afford them "the equal right to public manifestation and respect"; second that homosexuality derives from or is acceptable in respect of an "inborn predisposition"; third that "perverted manifestations of sexuality" can be compared to "the divinely established marital union of man and woman"; and fourth that it is legitimate for a person with transgender inclinations "to refuse the sex that has been given him or her by the Creator" and undergo surgery to that end. ${ }^{25}$

More recently, at the Holy and Great Council of the Orthodox Church held in 2016 in Crete, the topic of same-sex unions was also addressed. The relevant document reaches a conclusion not dissimilar to that of the Russian Orthodox synodal text, although expressed far more economically:

The Church does not allow for her members to contract same-sex unions or any other form of cohabitation apart from marriage. The Church exerts all possible pastoral efforts to help her members who enter into such unions understand the true meaning of repentance and love as blessed by the Church.

(The Holy and Great Council of the Orthodox Church 2018b)

All in all, it would seem that balanced, not to say sympathetic, treatments by Orthodox scholars of LGBTQIA+ experience and aspirations are rather rare. As John Chryssavgis (2011, 371) wryly observes:

There are some topics that Orthodox Christians are singularly uncomfortable about broaching - even if it is simply to affirm their outright rejection and unqualified condemnation-and homosexuality is certainly among them. (...) Indeed, one of my gravest concerns over the years is that the oppression of homosexuality and silence on sexual issues in a hierarchical institution, such as the Orthodox Church, not only results from unjustifiable and unacceptable ignorance and prejudice. It also results in the church's complicity in discrimination as well as the church's reticence concerning sexual abuse in our own communities.

Ciprian Toroczkai (2016) has provided a useful review of the available literature, agreeing with Chryssavgis that respectful discussion of what has 
traditionally been termed one of the "sins that cry to heaven" is in its infancy within the Orthodox Church. The author concludes that the official stance is not likely to change, established as this is by Scripture, patristic teaching, and canon law. Nonetheless, pastoral care can and should be developedand he sees evidence of this happening. If homosexuality remains an often taboo subject in Orthodox circles, even less theological attention appears to be given to the burgeoning field of LGBTQIA+ concerns and critiques. We have yet to see, for example, a significant Orthodox contribution to the discourse emerging around the groundbreaking work of Protestant theologian Megan DeFranza (2015) on intersex.

\section{Conclusion}

Traditional Orthodox ideas of gender in the historic Orthodox homelands of Eastern Europe and the Middle East may well prove to be increasingly at odds with what is de rigueur in the so-called diaspora, where, after a century or more of migration, the critical mass of faithful now live. The Orthodox continue to orient themselves along the geographical axis of the Christian East, in a variation on the disputed construct of "the West and the Rest" (Hall 1992). This can be seen in another document of the Great and Holy Council regarding inter-Orthodox cooperation in a defined set of Western countries (The Holy and Great Council of the Orthodox Church 2018a). ${ }^{26}$ While one may wish to problematize the import of "the West," the term remains a useful heuristic for charting an arguably widening divergence between those societies in which the Orthodox Church retains some kind of cultural or even political hegemony and those where Orthodox need to find their place in a rapidly changing pluralist landscape.

The present chapter has sought to outline the theological "topography" of the Orthodox tradition. Likely it has raised more questions than it has answered, in keeping with Evdokimov's $(1985,161)$ closing words to his The Sacrament of Love: "Human sexuality has never received a satisfactory explanation; perhaps it never will. The very transcendence of the Edenic state accounts for a certain vacillation of thought". Thankfully, the rest of this volume brings the reader from a descriptive to a prospective account of where Orthodoxy is and may be headed. If my response to the poignant queries of Gallaher with which we began is incomplete, we may at least be assured of having taken a step or more in the right direction.

\section{Notes}

1 I follow Ross Shepard Kraemer $(2008,466)$ in acknowledging, while suspending for the purposes of my chapter, the current Western trend toward questioning the very definition of "woman" (and "man"):

While cognizant of contemporary debates about gender identity and the imperfect mapping of gender categories onto actual persons, whether in 
modernity or in antiquity, I utilize the term "women" here as broadly and inclusively as possible to encompass those persons...we would recognize as such by twenty-first-century methods of discerning anatomical and genetic difference.

2 Thus-according to the majority of the Greek Fathers-Romans 5:12 reads: "As sin came into the world through one man and death through sin, so death spread to all men; and because of death, all men have sinned" (Meyendorff 1983, 144).

3 Valerie Karras (2008) is one influential voice appealing to the relative insignificance of gender difference prior to the Fall.

4 Alkiviadis Calivas (2003) urged that this aspect of churching be revised in an egalitarian direction; such a reform would correspond to earlier Orthodox practice - a critique reiterated more recently by Carrie Frederick Frost (2016). This revision has already been implemented in certain contexts, if not always on an official level (see the Introduction for this volume on the change of this practice in the Orthodox Church of Finland). There were isolated instances of the female diaconate being revived in the twentieth-century Greek Orthodox Church, with perhaps more yet to come in our time; the office has a greater, if still highly limited, prominence in the Armenian Apostolic Church. For an appraisal of the current status quo, see my contribution to a forthcoming anthology on the diaconate (Butcher 2019).

5 Elisabeth Behr-Sigel $(2008,15)$ can thus eloquently declare:

The image of the Theotokos carries a profound symbolism, in which the whole female being, biological and spiritual, becomes a sign of openness to God, to the inspiration of the Spirit, of the transparence of the creature to the beauty and tenderness of God. It is also the sign of a vocation to spiritual maternity-the birth in each man and woman of the new man in Christ, which is the vocation of the whole of humanity, called to become the whole Christ.

6 For a detailed account of the practices in Byzantium, see Taft (1998). While segregation of the sexes remains common in all the Eastern churches, the Oriental Orthodox actually have the opposite practice from that of the Byzantine-rite churches: in Assyrian, Syriac, Malankara, Coptic, Ethiopian, and Eritrean churches, men stand on the left and women on the right. Anecdotal evidence suggests that in both instances, however, the principle is to have the women on the right side, in keeping with Ps. 44/45:9 "At your right hand stands the queen in gold"). The difference is rather a matter of orientation, that is, whether one reckons right and left from a position facing the altar or looking toward the congregation from the altar.

7 There are rare exceptions such as St. Mary of Egypt (c. 344-c. 421 C.E.), who lacks the veil on account of the unique circumstances recounted in her canonical vita.

8 Evdokimov's most influential works are arguably The Sacrament of Love (1985) and Woman and the Salvation of the World (1994).

9 By contrast, the neuter gender of the Greek pneuma has not prevented the Byzantine tradition from calling upon the Holy Spirit as the "Heavenly King" in one of its most widely used prayers, while also adducing the arguably feminine epithet of "Giver of Life."

10 For Evdokimov, every woman is a mother, a "source of life," even if not biologically so, for she possesses an interior maternity: a vocation of protection, nurture, care, and fulfillment of need. Moreover, women personify human spiritual receptivity, with every person in turn called to be a mother, as it were, by giving birth to Christ. 
11 See the string of alpha-privative adjectives which come at the beginning of the ordinary Eucharistic formula of the Byzantine Rite, the Anaphora of St. John Chrysostom: "for You are God-ineffable, inconceivable, invisible, incomprehensible, always existing and ever the same" (Galadza, Roll, and Thompson 2004, 233-234). Of course, the word Trinity is feminine in Greek (triás), Slavonic, and many other languages. Although English renderings of Orthodox liturgical texts consistently avoid the issue by translating periphrastically, God is in fact called "She" in such instances as the first hymn after Holy Communion: after the priest declares "Save Your people, O God, and bless Your inheritance," the Greek text of the Liturgy has the people (or choir) respond with the literal equivalent of the following, "We have seen the true light. We have received the heavenly Spirit. We have found the true faith. We worship the undivided Trinity, for She has saved us." Even so, Orthodox theologians do not appear to be sympathetic to the kind of revisionism articulated by scholars such as Elizabeth Johnson (2000).

12 Hopko $(1993,148)$ elaborates on this point thus:

In a clash of symbolisms, which testifies to the divine mystery being revealed, (and so, say the saints, is to be fully expected), Jesus is not simply the brother to his disciples, as well as their master, lord, servant and friend. He is also their divine bridegroom, husband and head. Jesus is the new Adam; his church is the new Eve. He is the bridegroom; the church is his bride. He is the head; the church in his body. In this sense, the messiah may be said to be incomplete in himself. Jesus alone is not the whole Christ.

13 For a lucid treatment of this signal topic in modern Orthodox Trinitarian theology, see Gallaher (2016).

14 Thus Hopko $(1993,150)$ contends:

There is no possibility for naming God "mother" in the biblical tradition and in the liturgical and mystical life which this tradition engenders. And there is no possibility for naming God's Word "daughter." The use of the generic terms "parent" and "child" for the Father and the Son are unacceptable since they are theologically inaccurate and destructive of the familial and conjugal imagery in the church's scripture, liturgy and mystical experience. The terms "creator," "redeemer" and "sanctifier" (or "sustainer") for the three divine persons are also unacceptable because they not only are not names, but are misleading even as titles when applied to the distinct persons of the Holy Trinity, since the one God and Father creates, redeems, sanctifies and sustains the world through his divine Son and Word, and his Holy Spirit. There is no divine activity which is not the common activity of the three divine persons originating in the Father, enacted by the Son and accomplished by the Holy Spirit in perfect interpersonal unity.

15 St. Gregory represents an influential, if minority, view in the patristic tradition. For a nuanced treatment of his anthropology, see Smith (2004, 28-33).

16 Irene Galadza, "The Vocation of the Presbytera: Icon of the Theotokos in the Midst of the Ministerial Priesthood" (unpublished manuscript), cited in Peter Galadza $(2015,47)$.

17 For a detailed discussion of married saints in the Byzantine sanctoral, see my monograph (Butcher 2010) and an earlier form of this research, "Convoluted Conjugality: Hymnographic Repression, Transference and Co-optation in the Byzantine Sanctoral's Commemoration of Married Saints" in Logos: A Journal of Eastern Christian Studies 43-45 (2002-2004), 83-148.

18 "What is curious in the context of the ascetic movement is that women in the desert are usually prized and valorized for becoming 'male' or like 'men.' (...) 
there are some accounts of desert ascetics who, only after their death, when they need to be buried, were identified as being women, while all along the assumption has been that they were men. There are also fascinating reports of the physical and biological changes of women's bodies that occurred in the desert. (...) As the aim of the male ascetics in the desert was to become angelic by the metamorphosis of their body and their whole being, so too the aim of the female ascetics was to transcend their gender and the limitations that it posed to them" (Antonova 2013, 36-37).

19 E.g., St. Abramios (Oct. 29) and St. John of Kronstadt (Dec. 20).

20 Sung at Matins at the Ninth Ode on September 13, Dedication of the Church of the Anastasis in Jerusalem.

21 Anthony Ugolnik $(2001,285)$ has argued that discomfort with the male body is endemic to Orthodox piety as such:

Males "engender." Males "seminate." Males "penetrate," "fertilize" and "enact." (...) All of these acts, and much of the male organism which makes them possible, is purged from our imagery. (...) In religious terms, we men have lost the connection between our bodies and religious meaning.

Ugolnik $(2001,294)$ proceeds to contend that one contrast between the mysticism of Christian East and West is the reluctance in the former to give full rein to the kind of erotic imagery which comes to prevail in the latter.

22 The question of the ordination of women in the Orthodox Church has generated a burgeoning literature, to which this chapter cannot do justice. For a comprehensive, recent overview of the status quaestionis, see Vassiliadis, Papageorgiou, and Kasselouri-Hatzivassiliadi (2017).

23 On the significance of metaphor and on apophatic terminology within the liturgical discourse of the Byzantine Rite, see Butcher (2018), especially chapters three and four.

24 https://orthodoxyindialogue.com/. Accessed November 2018.

25 The document continues: "While treating people with homosexual inclinations with pastoral responsibility, the Church is resolutely against the attempts to present this sinful tendency as a 'norm' and even something to be proud of and emulate." Rather, such inclinations/conditions warrant spiritual remedies: "Homosexual desires, just as other passions torturing fallen man, are healed by the Sacraments, prayer, fasting, repentance, reading of Holy Scriptures and patristic writings, as well as Christian fellowship with believers who are ready to give spiritual support."

26 In order, these are listed as Canada, the United States of America, Latin America, Australia, New Zealand and Oceania, Great Britain and Ireland, France, Belgium, Holland and Luxembourg, Austria, Italy and Malta, Switzerland and Lichtenstein, Germany, the Nordic countries (except Finland), Spain, and Portugal.

\section{Bibliography}

Alfeyev, Metropolitan Hilarion. 2011. The Mystery of Faith: An Introduction to the Teaching and Spirtiuality of the Orthodox Church. Edited by Jessica Rose. Yonkers, NY: St Vladimir's Seminary Press.

Antonova, Stamenka E. 2013. "Chosen to Follow and to Lead: Women in the Ancient Christian Church." In Women in the Eastern Christian Tradition: Past Roles, Future Paradigms, edited by Stamenka E. Antonova, 15-37. New York: Theotokos Press. 
Ashbrook Harvey, Susan. 1993. "Feminine Imagery for the Divine: The Holy Spirit, the Odes of Solomon, and Early Syriac Tradition." St Vladimir's Theological Quarterly 37 (2-3): 111-139.

Behr-Sigel, Elisabeth. 2008. "Feminine Images and Orthodox Spirituality." The Ecumenical Review 60 (1-2) (January-April): 7-15.

Behr-Sigel, Elisabeth, and Kallistos Ware. 2000. The Ordination of Women in the Orthodox Church. Geneva: WCC Publications.

Boswell, John. 1995. Same-Sex Unions in Premodern Europe. New York: Vintage Books.

Butcher, Brian A. 2019. "Women Deacons in the Christian East." In The Diaconate in Ecumenical Perspective, edited by D. Michael Jackson. Durham: Sacristy Press.

Butcher, Brian A. 2018. Liturgical Theology after Schmemann: An Orthodox Reading of Paul Ricoeur. New York: Fordham University Press.

Butcher, Brian A. 2010. Married Saints in the Orthodox Tradition. Saarbrücken: VDM Verlag.

Calivas, Alkiviadis C. 2003. Aspects of Orthodox Worship, Vol. 3 of Essays in Theology and Liturgy. Brookline, MA: Holy Cross Orthodox Press.

Chryssavgis, John. 2011. Homosexuality in the Orthodox Church. St Vladimir's Theological Quarterly 55 (3): 371-373.

Contos, Leonidas, trans., and Spencer T. Kezios, ed. and comp. 1995. Sacraments and Services: Book Two. Northridge, CA: Narthex Press.

DeFranza, Megan K. 2015. Sex Difference in Christian Theology: Male, Female, and Intersex in the Image of God. Grand Rapids, MI: Eerdmans.

Evdokimov, Paul. 1994. Woman and the Salvation of the World. Crestwood, NY: St Vladimir's Seminary Press.

Evdokimov, Paul. 1985. The Sacrament of Love. Crestwood, NY: St Vladimir's Seminary Press.

Frederick Frost, Carrie. 2016. "The Time Has Come: The Why and the How of Bringing Change to the Postpartum Rites of the Orthodox Church." In Love, Marriage and Family in Eastern Orthodox Perspective, edited by Theodore Grey Dedon and Sergey Trostyanskiy, 245-252. Piscataway, NJ: Gorgias Press.

Galadza, Peter. 2015. "The Priest's Wife: A Vocation in Her Own Right-and Rite." INTAMS Review: Journal for the Study of Marriage and Spirituality 21 (1) (Summer): 43-52.

Galadza, Peter, exec. ed., Joseph Roll and J. Michael Thompson, eds. 2004. The Divine Liturgy: An Anthology for Worship. Ottawa: Metropolitan Andrey Sheptytsky Institute of Eastern Christian Studies.

Gallaher, Brandon. 2018. "Tangling with Orthodox Tradition in the Modern West: Natural Law, Homosexuality, and Living Tradition." The Wheel 13-14 (SpringSummer): 51-63.

Gallaher, Brandon. 2016. Freedom and Necessity in Modern Trinitarian Theology. Oxford Theology and Religion Monographs. Oxford: Oxford University Press.

Hall, Stuart. 1992. "The West and the Rest: Discourse and Power." In The Formations of Modernity, Book 1 of Understanding Modern Societies: An Introduction, edited by Bram Gieben and Stuart Hall, 276-331. Cambridge: Polity Press.

Harrison, Nonna Verna. 2013. "Monasticism, Marriage, and Theological Anthropology: Which Is Better?" In Women in the Eastern Christian Tradition: Past Roles, Future Paradigms, edited by Stamenka E. Antonova, 120-134. New York: Theotokos Press. 
The Holy and Great Council of the Orthodox Church. 2018a. "Official Documents of the Holy and Great Council of the Orthodox Church: The Orthodox Diaspora.” Accessed May 15, 2019. https://www.holycouncil.org/-/diaspora.

The Holy and Great Council of the Orthodox Church. 2018b. "Official Documents of the Holy and Great Council of the Orthodox Church: The Sacrament of Marriage and Its Impediments.” Accessed May 15, 2019. https://www.holycouncil. org/-/marriage.

Hopko, Thomas. 1993. "God and Gender: Articulating the Orthodox View." St Vladimir's Theological Quarterly 37 (2-3): 141-183.

Humphrey, Edith M. 2017. Further Up and Further In: Orthodox Conversations with C. S. Lewis on Scripture and Theology. Yonkers, NY: St Vladimir's Seminary Press.

Johnson, Elizabeth. 2000. "Naming God She: The Theological Implications." Boardman Lecture XXXVII, edited by Sandy Russell. Philadelphia, PA: Boardman Lectureship in Christian Ethics 5. https://repository.upenn.edu/boardman/5.

Karras, Valerie. 2008. "Orthodox Theologies of Women and Ordained Ministry." In Thinking Through Faith: New Perspectives from Orthodox Christian Scholars, edited by Aristotle Papanikolaou and Elizabeth H. Prodromou, 113-158. Crestwood, NY: Saint Vladimir's Seminary Press.

Kraemer, Ross Shepard. 2008. "Women and Gender." In The Oxford Handbook of Early Christian Studies, edited by Susan Ashbrook Harvey and David G. Hunter, 465-492. New York: Oxford University Press.

Larin, Vassa. 2008. "What Is 'Ritual Im/purity' and Why?” St Vladimir's Theological Quarterly 52 (3-4): 275-292.

Lash, Ephrem. n.d. “The Menaion.” Accessed May 15, 2019. http://newbyz.org/ lashmenaion.html.

Louth, Andrew. 2013. Introducing Eastern Orthodox Theology. Downers Grove, IL: IVP Academic.

McGuckin, John A. 2017. Illumined in the Spirit: Studies in Orthodox Spirituality. Crestwood, NY: St Vladimir's Seminary Press.

Meyendorff, John. 1983. Byzantine Theology: Historical Trends and Doctrinal Themes. New York: Fordham University Press.

Pelikan, Jaroslav. 1986. The Vindication of Tradition: The 1983 Jefferson Lecture in the Humanities. New Haven, CT: Yale University Press.

Phan, Peter C. 1990. "Gender Roles in the History of Salvation: Man and Woman in the Thought of Paul Evdokimov." Heythrop Journal 31 (1) (January): 53-66.

Rapp, Claudia. 2016. Brother-Making in Late Antiquity and Byzantium: Monks, Laymen, and Christian Ritual. Oxford: Oxford University Press.

The Russian Orthodox Church. 2000. "The Basis of the Social Concept: Section XII. Problems of Bioethics.” The Russian Orthodox Church, Department for External Church Relations. Accessed May 15, 2019. https://mospat.ru/en/ documents/social-concepts/xii/.

Smith, J. Warren. 2014. Passion and Paradise: Human and Divine Emotion in the Thought of Gregory of Nyssa. New York: Crossroad Publishing Company.

Taft, Robert F. 1998. "Women at Church in Byzantium: Where, When-and Why." Dumbarton Oaks Papers 52: 27-87.

Thomas, Stephen. 2011. "Deification.” In The Encyclopedia of Eastern Orthodox Christianity, Vol. 1, edited by John Anthony McGuckin, 182-187. Malden, MA: Wiley-Blackwell. 


\section{Brian A. Butcher}

Toroczkai, Ciprian Iulian. 2016. "Homosexuality from a Contemporary Orthodox Perspective.” Review of Ecumenical Studies, Sibiu 8 (3, December): 401-422.

Ugolnik, Anthony. 2001. "Living in Skin: Sex, Spirituality, and the Christian Male." In Windows to the East: Eastern Christians in a Dialogue of Charity, edited by Jaroslav Z. Skira and Myroslaw I. Tataryn, 283-316. Ottawa: Novalis.

Vassiliadis, Petros, Niki Papageorgiou, and Eleni Kasselouri-Hatzivassiliadi, eds. 2017. Deaconesses, the Ordination of Women and Orthodox Theology. Newcastle upon Tyne: Cambridge Scholars Publishing.

Wesche, Kenneth Paul. 1993. "Man and Woman in Orthodox Tradition: The Mystery of Gender.” St Vladimir's Theological Quarterly 37 (2-3): 213-251.

Wheeler, Michael. 2011. "Martin Heidegger.” Stanford Encyclopedia of Philosophy. Accessed August 25, 2019. https://plato.stanford.edu/entries/heidegger/. 